\title{
PRELIMINARY RESULTS OF THE BIPOLAR TECHNIQUE IN THE TREATMENT OF NEUROMUSCULAR SCOLIOSIS
}

\author{
RESULTADOS PRELIMINARES DA TÉCNICA BIPOLAR NO TRATAMENTO DA ESCOLIOSE \\ NEUROMUSCULAR
}

\section{RESULTADOS PRELIMINARES DE LA TÉCNICA BIPOLAR EN EL TRATAMIENTO DE LA ESCOLIOSIS NEUROMUSCULAR}

\author{
Robson Cruz de Oliveliat, Helton luiz Aparecido Defino', Herton Rodrigo Tavares Costa ${ }^{1}$ \\ 1. Universidade de São Paulo, Faculdade de Medicina de Ribeirão Preto, Department of Orthopedics and Traumatology, Ribeirão Preto, SP, Brazil.
}

\begin{abstract}
Objective: To present the preliminary results of the bipolar technique for the surgical treatment of neuromuscular spine deformities. Methods: Five patients with neuromuscular scoliosis (cerebral palsy - 3 patients, spinal amyotrophy - 1 patient, and genetic syndrome - 1 patient) underwent surgical treatment using the bipolar technique and were evaluated 12 months after the operation. Results: General care and the ability to sit improved in all patients. The main curve ranged from 64.7 to 84.1 degrees (mean $70.58 \pm 7.1$ ) in the preoperative period and from 2.6 to 50.3 degrees (mean $25.50 \pm 16.0$ ) in the postoperative period with $64 \%$ correction. Corrections of pelvic obliquity (85\%), T4-T12 kyphosis (43\%), the Pisa angle (69\%) and the sacroclavicular angle (60\%) were observed 12 months following surgery. Postoperative infection (2 patients) and pneumonia (1 patient) were the complications observed. Conclusion: The bipolar technique presented good clinical and radiological results associated with low morbidity in the treatment of neuromuscular spine deformities. Level of evidence IV; Case series.
\end{abstract}

Keywords: Scoliosis; Neuromuscular Diseases; Minimally Invasive Surgical Procedures; Deformities.

\section{RESUMO}

Objetivo: Apresentar os resultados preliminares da técnica bipolar no tratamento cirúrgico das deformidades neuromusculares da coluna vertebral. Métodos: Cinco pacientes com escoliose neuromuscular (paralisia cerebral - três pacientes, amiotrofia espinhal - um paciente, e síndrome genética - um paciente) foram submetidos ao tratamento cirúrgico por meio da técnica bipolar e avaliados 12 meses depois da cirurgia. Resultados: Os cuidados gerais e a capacidade de sentar apresentaram melhora em todos os pacientes. A curva principal variou de 64,7 a 84,1 graus (média 70,58 \pm 7,1) no pré-operatório e de 2,6 a 50,3 graus (média 25,50 \pm 16,0) no pós-operatório, com correção de 64\%. A correção da obliquidade pélvica (85\%), de cifose T4-T12 (43\%), do ângulo de Pisa (69\%) e do ângulo sacro clavicular (60\%) foi observada depois de 12 meses de pós-operatório. Infecção pós-operatória (dois pacientes) e pneumonia (um paciente) foram as complicações observadas. Conclusão: A técnica bipolar apresentou bons resultados clínicos e radiológicos associados a pequena morbidade no tratamento de deformidades neuromusculares da coluna vertebral. Nível de evidência IV; Série de casos.

Descritores: Doenças Neuromusculares; Procedimentos Cirúrgicos Minimamente Invasivos; Deformidades.

\section{RESUMEN}

Objetivo: Presentar los resultados preliminares de la técnica bipolar en el tratamiento quirúrgico de las deformidades neuromusculares de la columna. Métodos: Cinco pacientes con escoliosis neuromuscular (parálisis cerebral - 3 pacientes, amiotrofia espinal - 1 paciente y síndrome genético - 1 paciente) fueron sometidos a tratamiento quirúrgico mediante técnica bipolar y evaluados a los 12 meses de cirugía. Resultados: Los cuidados generales y la capacidad de sentarse mejoraron en todos los pacientes. La curva principal osciló entre 64,7 y 84,1 grados (media 70,58 \pm 7,1) en el preoperatorio y entre 2,6 y 50,3 grados (media 25,50 \pm 16,0) en el postoperatorio con una corrección del 64\%. La corrección de oblicuidad pélvica (85\%), cifosis T4-T12 (43\%), ángulo de Pisa (69\%) y ángulo clavicular sacro (60\%) se observó a los 12 meses del posoperatorio. Infección postoperatoria (2 pacientes) y neumonía (1 paciente) fueron las complicaciones observadas. Conclusión: La técnica bipolar mostró buenos resultados clínicos y radiológicos asociados a la reducción de la morbilidad en el tratamiento de las deformidades neuromusculares de la columna. Nivel de evidencia IV; Serie de casos.

Descriptores: Enfermedades Neuromusculares; Procedimientos Quirúrgicos Mínimamente Invasivos; Deformidades.

Study conducted at the Hospital das Clínicas da Faculdade de Medicina de Ribeirão Preto, Ribeirão Preto, SP, Brazil.

Correspondence: Robson Cruz de Oliveira. Rua Lídia Catureli Giroti, 51/126, Jardim Botânico, Ribeirão Preto, SP, Brasil. 14021-578. robsoncruzoliveira@yahoo.com.br 


\section{INTRODUCTION}

Neuromuscular deformities of the spine represent a heterogeneous group of deformities with different etiologies that affect the brain, spinal cord, peripheral nerves, the neuromuscular junction or muscles. ${ }^{1}$ This modality of spinal deformity generally does not respond the conservative treatment and the progression of the deformity does not cause only problems related to the patient's appearance. ${ }^{2}$ The progression of spinal deformity can interfere with respiratory function, functional activities and patient care. ${ }^{1,3}$ The pelvic obliquity due to muscle imbalance is present in a large percentage of patients with neuromuscular scoliosis and can interfere with the balance of the pelvis and the trunk. Pelvic obliquity destabilizes the base for maintaining the sitting position, which is the position adopted by a large percentage of these patients due to their altered neuromuscular function. ${ }^{2-4}$

Children with deformities of neuromuscular etiology often develop progressive spinal deformity accompanied by cardiorespiratory impairment. The risk of progression of the deformity is inversely proportional to the patient's gait ability. ${ }^{5}$

Surgical treatment is indicated in the presence of an increase in deformity and aims to correct the deformity, improve respiratory function, improve functional activity and patient care ${ }^{6,7}$ The surgical treatment is more complex than surgical treatment for idiopathic scoliosis, and arthrodesis with spinal fixation is more extensive, requiring inclusion of the pelvis in many patients. Postoperative complications occur more frequently compared to correction of other types of spinal deformity.

The surgical treatment of spinal deformities of neuromuscular etiology aim to stabilize the trunk and correct the deformity and pelvic obliquity by means of instrumentation and arthrodesis involving the entire extension of the spine..$^{1,2}$ Improved quality of life, of function and of patient care have been reported with surgical treatment. ${ }^{8}$

The percentage of morbidity and complications from neuromuscular deformity surgery is higher than that of idiopathic scoliosis, exceeding $17 \%, 9,10$ The reduction in morbidity related to surgical treatment has led to a trend towards increased acceptance in the spinal surgery milieu and this tendency encompasses the surgical treatment of deformities. ${ }^{3,4}$ The least invasive technique for the correction of neuromuscular deformities was developed by Miladi et al., who reported significant correction of spinal deformities, pelvic obliquity and patient care using a less invasive technique with less morbidity and a reduced complication rate. ${ }^{3}$

The results of the technique described by Miladi ${ }^{3}$ and the lower morbidity of the procedure compared to traditional surgical correction motivated the introduction of this method, still little used in Brazil. The objective of this study is to report the preliminary results from the use of the Miladi technique in the treatment of neuromuscular spine deformities.

\section{METHODS}

This prospective observational study was conducted at the Hospital das Clínicas of the Faculdade de Medicina de Ribeirão Preto - São Paulo, having been approved by the local Institutional Review Board as number 1687/2021. Five patients (two male and three female) with neuromuscular scoliosis, ranging in age from 10 years and seven months to 18 years and one month (mean of 13 years and 11 months), who underwent surgical treatment using the bipolar technique and follow-up over a period of 12 months, were included in the study. The etiology of the scoliosis was cerebral palsy in three patients, progressive type III muscle amyotrophy in one patient and undetermined genetic syndrome in one patient. The demographic patient data are illustrated in Table 1. The pattern of the curves was thoracolumbar in four patients and double curves in one patient. All the patients had pelvic obliquity (Figure 1).

Surgical treatment was indicated due to the progression of the curve or the pelvic obliquity associated with an inability to maintain the trunk in a sitting position. Three patients were unable to maintain a sitting position (Figure 2).

The surgical procedure was performed under general anesthesia with the patient under traction of the head and lower limbs. The proximal region of the thoracic and lumbosacral spines was exposed through isolated incisions in the midline. In the proximal region, the instrumentation was performed bilaterally by means of hooks (pedicular and laminar) with the application of compression force between them to act as claws. In the distal part, a bilateral iliosacral screw coupled to the multiaxial connector was used to fix the rods (Figure 3 )

The rods coupled to the proximal region hooks and to the distal multiaxial connectors were connected bilaterally to a long rod that was introduced through the musculature without requiring exposure of the entire extension of the deformity. The long rod was modeled according to the spinal deformity and connected to the proximal and distal rods by means of lateral rod connectors. The long, $5.5 \mathrm{~mm}$ diameter, chromium-cobalt rod was positioned medially to the distal rod.

The patients were evaluated 12 months after the surgical procedure using clinical parameters that considered cosmetic improvement of the deformity, improved ability to sit and support the trunk and improvement of patient healthcare conditions. The radiological parameters evaluated were the angulation of the main curve and kyphosis (T4-T12) using the Cobb method, pelvic obliquity, the Pisa angle (angle between the vertical line of the sacrum and the vertical line that passes through the center of C7) and the sacroclavicular angle. Intra- and postoperative complications were also evaluated.

\section{RESULTS}

The patients were evaluated 12 months after undergoing surgery. Cosmetic improvement of the deformity and the improvement in general patient care were observed (Figure 4).

The results of the evaluation of the radiographic parameters (angle of the curve, T4-T12 kyphosis, pelvic obliquity, Pisa angle and sacroclavicular angle) are shown in Table 2 and Figure 5, and significant correction of the parameters was observed.

No intra- or postoperative neurological complications were observed, but two patients presented postoperative infection and pneumonia was observed in one patient. No loosening, breakage or other implant issues were observed 12 months after surgery.

Table 1. Patient demographic data.

\begin{tabular}{|c|c|c|c|c|c|}
\hline & Patient 1 & Patient 2 & Patient 3 & Patient 4 & Patient 5 \\
\hline Age & $13 Y 8 M$ & $15 Y 10 M$ & 10Y 7M & $11 Y 6 M$ & $18 \mathrm{Y} 1 \mathrm{M}$ \\
\hline Etiology & CP/ GMFCS V & $\begin{array}{c}\text { Progressive type } 3 \text { spinal } \\
\text { amyotrophy }\end{array}$ & $\begin{array}{l}\text { Undetermined genetic } \\
\text { syndrome }\end{array}$ & CP/ GMFCS V & CP/ GMFCS IV \\
\hline Complication & Deep infection & - & - & $\begin{array}{c}\text { Pneumonia/ Deep } \\
\text { infection }\end{array}$ & - \\
\hline Able to sit & No & Yes & Yes & No & No \\
\hline Curve pattern & Thoracolumbar & Thoracolumbar & $\begin{array}{c}\text { Double thoracolumbar } \\
\text { curve }\end{array}$ & Thoracolumbar & Thoracolumbar \\
\hline
\end{tabular}




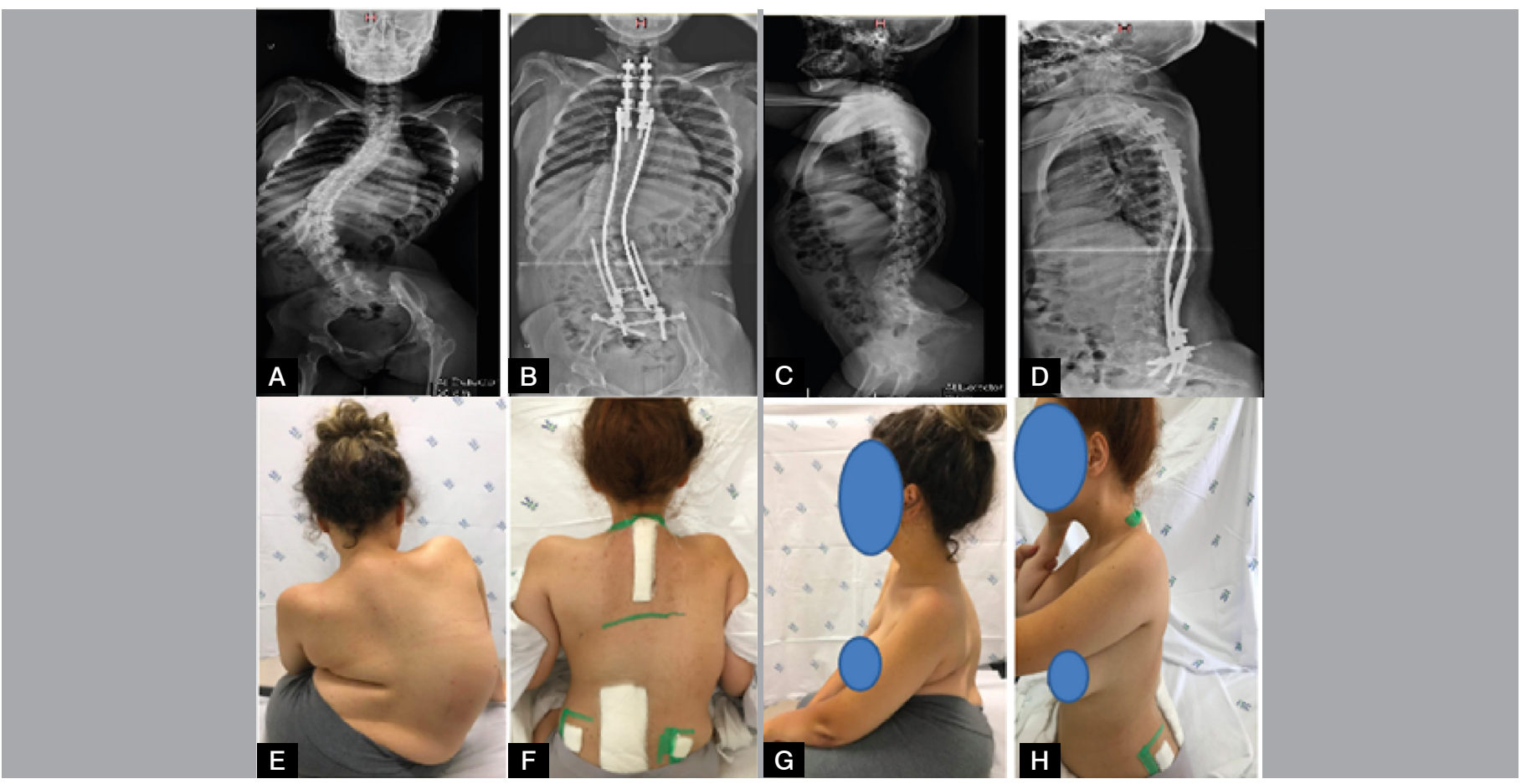

Figure 1. 15-year-old patient with progressive type III spinal amyotrophy. (A) preoperative AP radiography, (B) immediate postoperative AP radiograph, (C ) preoperative lateral radiograph, (D) immediate postoperative lateral radiograph, $(E-H)$ patient showing the deformity and pelvic obliquity in the pre- and immediate postoperative periods.
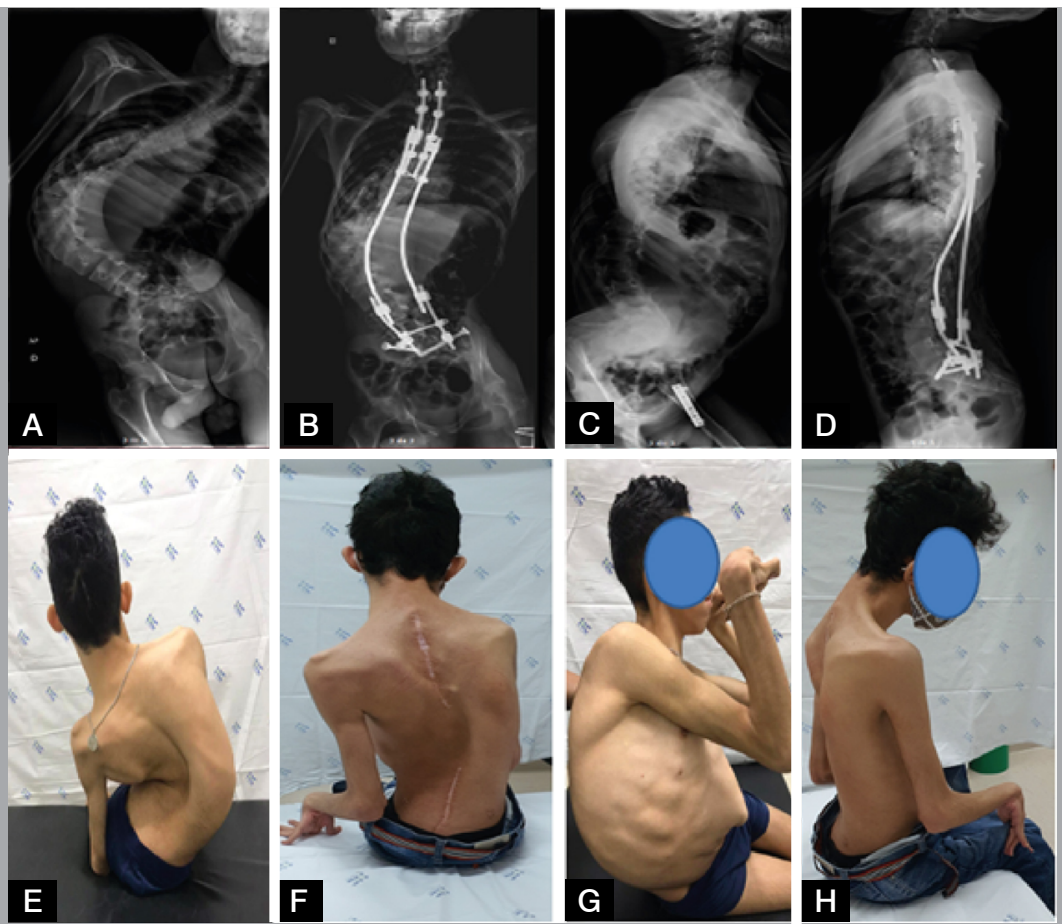

Figure 2. 18-year-old patients with cerebral palsy. (A) preoperative AP radiograph, (B) postoperative radiograph after 12 months of evolution, (C) preoperative lateral radiograph, (D) postoperative lateral radiograph after 12 months of evolution, $(\mathrm{E}-\mathrm{H})$ clinical photographs of the patient prior to surgery and 12 months following surgery

\section{DISCUSSION}

The clinical and radiographic results of the surgical treatment of neuromuscular scoliosis using the Miladi bipolar technique were highly satisfactory in the 12-month postoperative evaluation according to the parameters used. The bipolar technique allowed the satisfactory correction of the deformity, the obliquity of the pelvis and the trunk alignment by means of less invasive surgery with less morbidity. Preliminary results have shown that the surgical treatment objective can be achieved through surgery with less morbidity and fewer postoperative complications. It was possible to perform the surgical procedure in a patient with severe deformity and low weight, in which case the conventionally used technique could have been contraindicated.

The principle behind the bipolar treatment technique does not 
perform arthrodesis of the entire instrumented extension of the spine and totally opposes the concept of fixation and arthrodesis that has classically been utilized in the surgical treatment of neuromuscular scolioses. ${ }^{2,3}$

Neuromuscular scoliosis is characterized by long C-shaped curves that cause spinal collapse, pelvic obliquity and deviation in the sagittal plane..$^{2,6,11}$ The classical corrective surgical technique was based on segmental spinal fixation and fixation of the entire extension of the spine and different spinal fixation techniques were developed towards this end, from the segmental fixation of the spinous processes recommended by Resina and Alves, to the sublaminar cerclage described by Luque, to the sublaminar bands described by Mazda, to pedicle screws or hybrid fixations.,12 Pelvic fixation, used in patients who have pelvic obliquity, also underwent technical evolution with the use of iliac rods (Galveston), iliac screws, S2-alar-iliac screws, and iliosacral screws. ${ }^{2,13}$

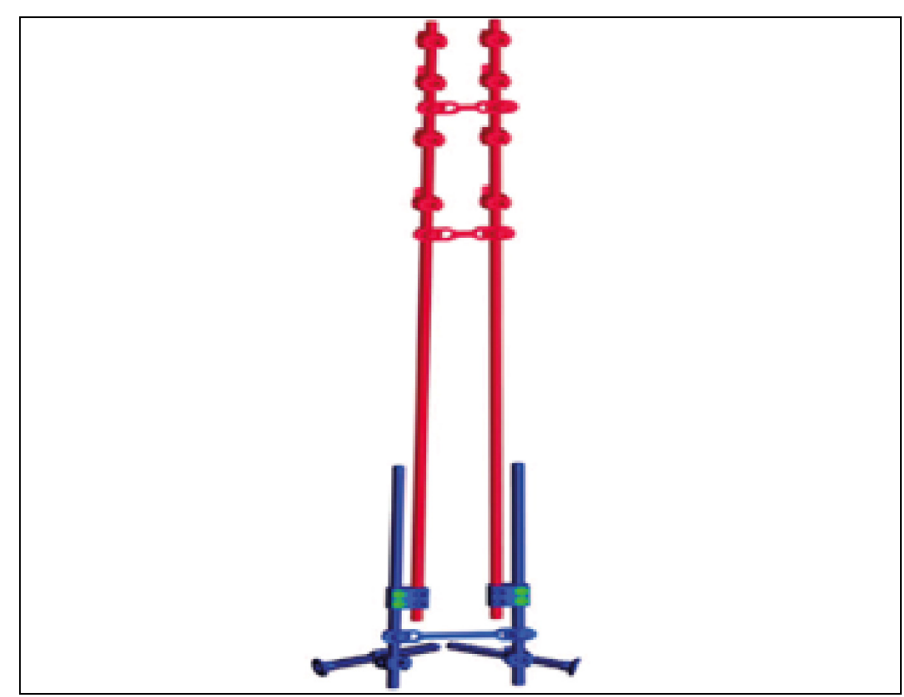

Figure 3. Bipolar construction, performed distally with iliosacral screws and proximally with double claw hooks.

However, despite the evolution of fixation techniques, the rate of complications associated with the overall conditions of the patients has been extremely high due to the large extent of the surgical procedure. ${ }^{11,13}$

About $40.1 \%$ of complications have been reported as general complications from surgical treatment for neuromuscular scoliosis. ${ }^{14}$ The postoperative complications can be early (infection, cardiorespiratory, nutritional, ileus, bedsores, bleeding and death) or late (infection, pseudoarthrosis, breakage or loosening of the implants and correction loss). ${ }^{15,16}$

The bipolar fixation method described by Miladi considers that performing arthrodesis is not necessary in patients with neuromuscular scoliosis and who do not walk, and that spontaneous ankylosis

Table 2. Results of the radiographic parameter evaluation.

\begin{tabular}{|c|c|}
\hline Radiographic parameter & Value \\
\hline \multicolumn{2}{|l|}{ Main curve (Cobb angle) } \\
\hline Preoperative & 70.58 (64.7 to 84.1$)$ \\
\hline Postoperative & 25.50 (2.6 to 50.3$)$ \\
\hline Correction (\%) & $64 \%$ \\
\hline \multicolumn{2}{|l|}{ Pelvic obliquity } \\
\hline Preoperative & $13.70(0.7$ to 24.9$)$ \\
\hline Postoperative & $2.06(0.0$ to 6.1$)$ \\
\hline Correction (\%) & $85 \%$ \\
\hline \multicolumn{2}{|l|}{ T4-T12 Kyphosis } \\
\hline Preoperative & 20.42 (13.7 to 33.8) \\
\hline Postoperative & 11.68 (2.8 to 19.8$)$ \\
\hline Correction (\%) & $43 \%$ \\
\hline \multicolumn{2}{|l|}{ Pisa angle } \\
\hline Preoperative & 56.34 (31.7 to 102.7$)$ \\
\hline Postoperative & 17.80 (3.70 to 28$)$ \\
\hline Correction (\%) & $69 \%$ \\
\hline \multicolumn{2}{|l|}{ Sacroclavicular angle (SCA) } \\
\hline Preoperative & 37.98 (26 to 72$)$ \\
\hline Postoperative & 12.26 (3.70 to 16.80$)$ \\
\hline Correction (\%) & $60 \%$ \\
\hline
\end{tabular}
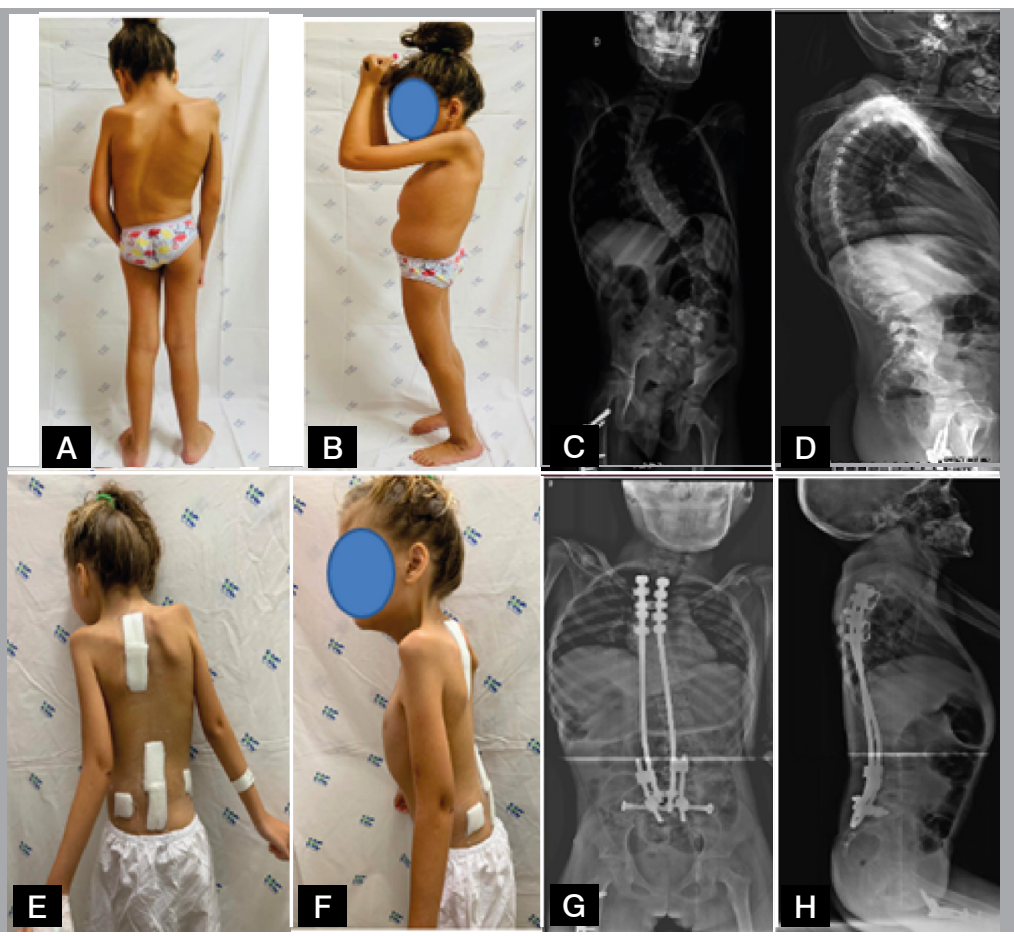

Figure 4. 10-year-old patient with undetermined genetic syndrome. (A and B) preoperative photographs of the patient, (C and D) Preoperative AP and lateral radiographs, $(E$ and $F)$ patient in the immediate postoperative period, $(G$ and $H) A P$ and lateral postoperative radiographs. 


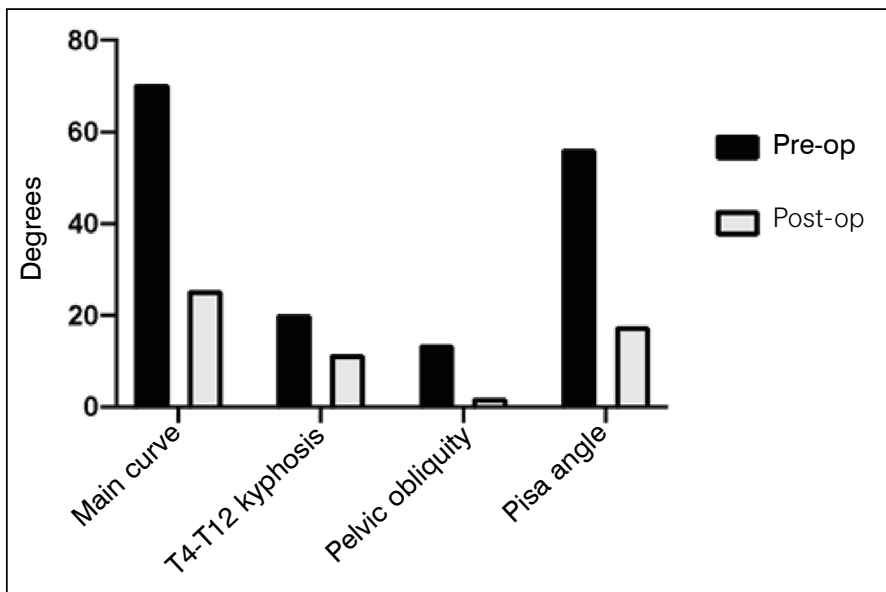

Figure 5. Results of the radiographic parameter evaluation.

has been reported in a large number of the patients who have undergone fixation without arthrodesis., Miladi believes that early surgery using a solid and stable base by means of a less invasive approach, even without arthrodesis, leads to more satisfactory results and allows stretching of the fixation. ${ }^{3,4}$

The Miladi technique is supported by the biomechanical concept of rigid fixation of the proximal and distal parts to allow correction of the deformity by the effect of distraction. The elasticity of the rods, the polyaxial connector, and the mode of the fixation assembly, permit the absorption of mechanical stress. Because of this elasticity, rod breakage has rarely been observed and only one patient out of a group of 100 patients operated by this technique experienced rod breakage. ${ }^{3,4,17}$ By preserving the intermediate area between the proximal and distal components of the fixation the segmental mobility of the spine is maintained and allows stretching of the rods of the system to increase correction. ${ }^{17,18}$

The experience of the creator of the bipolar technique for the correction of neuromuscular spine deformities has yielded highly satisfactory results and its use has been expanded to treat other spinal deformities. ${ }^{19}$

\section{CONCLUSIONS}

Our preliminary experience using the bipolar technique in the treatment of neuromuscular deformities, even taking the learning curve and the small number of patients into account, has been highly satisfactory and presents an alternative in the surgical treatment of neuromuscular deformities with little morbidity in this group of patients for whom surgical treatment normally presents high morbidity.

All authors declare no potential conflict of interest related to this article.

CONTRIBUTION OF THE AUTHORS: Each author made significant individual contributions to this manuscript. RCO: active participation in the discussion of the results, review and approval of the final version of the work. HLAD: active participation in the discussion of the results, review and approval of the final version of the work. HRTC: active participation in the discussion of the results, review and approval of the final version of the work.

\section{REFERENCES}

1. Halawi MJ, Lark RK, Fitch RD. Neuromuscular Scoliosis: Current Concepts. Orthopedics. 2015;38(6):e452-6. doi: 10.3928/01477447-20150603-50.

2. McCarthy RE. Management of neuromuscular scoliosis. Orthop Clin North Am 1999;30(3):435-49. doi: 10.1016/s0030-5898(05)70096-1

3. Miladi L, Gaume M, Khouri N, Johnson M, Topouchian V, Glorion C. Minimally Invasive Surgery for Neuromuscular scoliosis: results and complications in a series of one hundred patients. Spine (Phila Pa 1976). 2018;43(16):e968-5. doi: 10.1097/ BRS.0000000000002588.

4. Miladi F. The minimally invasive bipolar technique for the treatment of spinal deformities in children and adolescents. Coluna/Columna. 2020;19(4):308-13. doi: 10.1590/ s1808-185120201904238288.

5. Canavese F, Rousset M, Le Gledic B, Samba A, Dimeglio A. Surgical advances in the treatment of neuromuscular scoliosis. World J Orthop. 2014:5(2):124-33. doi: 10.5312/wjo. v5.i2.124.

6. Jacob Júnior C, Barbosa IM, Batista Júnior JL, Leonel RB, Perim LGL, Oliveira TGS. Assessment of bone density in patients with scoliosis neuromuscular secondary to cerebral palsy. Coluna/Columna. 2014;13(3):193-5. doi: 10.1590/S1808-18512014130300R80

7. Rosa FFS, Mendoza MAL, Pontin JCB. Epidemiological profile and outcomes in postoperative neuromuscular escoliosis. Coluna/Columna. 2020;19(1):26-9. doi: 10.1590/ s1808-185120201901220734

8. Olafsson Y, Saraste H, Al-Dabbagh Z. Brace treatment in neuromuscular spine deformity. J Pediatr Orthop. 1999;19(3):376-9.

9. Reames DL, Smith JS, Fu KMG, Polly Jr. DW, Ames CP. Berven SH, et al. Complications in the surgical treatment of 19,360 cases of pediatric scoliosis: a review of the Scoliosis Research Society Morbidity and Mortality database. Spine (Phila PA 1976). 2011;36(18):148491. doi: 10.1097/BRS.0b013e3181f3a326.

10. Bachy M, Bouyer B, Vialle R. Infections after spinal correction and fusion for spinal deformities in childhood and adolescence. Int Orthop. 2012;36(2):465-9. doi: 10.1007/s00264-011-1439-8.
11. Rocha LEM, Pudles E, Lampert HB. Avaliação dos resultados do tratamento cirúrgico da escoliose na atrofia muscular espinhal tipo 2. Coluna/Columna. 2011;10(3):211-5. doi: 10.1590/S1808-18512011000300009.

12. Odent $T$, llharreborde $B$, Miladi $L$, Khouri $N$, Violas $P$, Ouellet $J$, et al. Fusionless surgery in early-onset scoliosis. Orthop Traumatol Surg Res. 2015;101(6 Suppl):S281-8. doi: 10.1016/j.otsr.2015.07.004

13. Miladi LT, Ghanem IB, Draoui MM, Zeller RD, Dubousset JF. lliosacral screw fixation for pelvic obliquity in neuromuscular scoliosis. A long-term follow-up study. Spine (Phila Pa 1976). 1997:22(15):1722-9. doi: 10.1097/00007632-199708010-00007

14. Rumalla K, Yarbrough CK, Pugely AJ, Koester L, Dorward IG. Spinal fusion for pediatric neuromuscular scoliosis: national trends, complications, and in-hospital outcomes. J Neurosurg Spine. 2016;25(4):500-8. doi: 10.3171/2016.2.SPINE151377.

15. Sharma S, Wu C, Andersen T. Wang Y. Hansen ES, Bünger CE. Prevalence of complications in neuromuscular scoliosis surgery: a literature meta-analysis from the past 15 years. Eur Spine J. 2013;22(6):1230-49. doi: 10.1007/s00586-012-2542-2.

16. Santos DC Cavali PTM Santos MAM, Lehoczki MA Rossato AJ, Landim E Tratamento cirúrgico da escoliose em pacientes com amiotrofia espinhal com parafusos pediculares (instrumental de 3 geração) e complicações precoces. Coluna/Columna. 2010;9(2):98103. doi: 10.1590/S1808-18512010000200003

17. Arlet $\mathrm{V}$, Liljenqvist $U$, Miladi L, Aebi M. New concepts in scoliosis treatment. Eur Spine J. 2013;22(Suppl 2):79-80. doi: 10.1007/s00586-013-2673-0.

18. Bouthors C, Gaume M, Glorion C, Miladi L. Outcomes at skeletal maturity of 34 children with scoliosis treated with a traditional single growing rod. Spine (Phila Pa 1976). 2019;44(23):1630-37. doi: 10.1097/BRS.0000000000003148.

19. Wolf W, Habboubi K, Sebaaly A, Moreau PE, Miladi I, Riouallon G. Correction of adult spinal deformity with a minimally invasive fusionless bipolar construct: preliminary results. Orthop Traumatol Surg Res. 2019;105(6):1149-55. doi: 10.1016/j. otsr.2019.02.015. 